\title{
SEJARAH PERKEMBANGAN HISAB DAN RUKYAT
}

\author{
Oleh : Ehsan Hidayat \\ Pascasarjana Ilmu Falak UIN Walisongo Semarang \\ ehsan.hidayat@gmail.com
}

\begin{abstract}
Hisab and rukyat are two methods used in the determination of the Muslim worship time, such as Ramadan fast, five times prayer, Eid al-Adha sacrifice, and also for the benefit of human in general. observation of the sky made by humans is an activity that is closely related to the needs of man himself. History summarizes the journey of Falak science treasures in the early determination of the kamariyah months from the discovery of classical methods to development in the modern era. The initial method used was the role of both eyes as the human optic of the moment to see the moon on the 29th of the lunar month. And as the times progressed to the method of rukyatul hilal by combining the modern product of the telescope. The position of reckoning that one side of the rukyah can not be separated in its development. Known at the time of the dinas umayah development of astronomy began to be shaken, that is with the translation of the prime work of books of astronomy from Greek to Arabic. Miftah an-nujum that is adopted into hermes is the first Muslim heart book. And to the works of the modern era that colored many of rukyat itself.
\end{abstract}

Keyword: Hisab and rukyat, the beginning of the month kamariyah, history

\section{A. Pendahuluan}

Rukyah (observasi ${ }^{1}$ ) merupakan salah satu metode yang digunakan umat manusia untuk mengamati benda-benda langit (dalam Islam digunakan untuk menentukan momentum ibadah, seperti salat, puasa, haji dan lain sebagainya). Kata rukyah erat dengan pembahasan hisab (perhitungan) yang juga menjadi salah satu metode pendukungnya. Hal ini dikarenakan keduanya disimbolkan sebagai dua sisi mata uang yang saling melengkapi.

Dalam catatan sejarah, rukyah merupakan suatu metode yang digunakan lebih dahulu oleh umat manusia daripada hisab. Hal ini karena rukyah lebih mudah

${ }^{1}$ Observasi merupakan makna yang diadopsi dari kata رصد - برصد - رصد yang artinya mengintip, mengintai, observasi. Dalam lisan al-'Arab disebutkan bahwa akar kata rashada mempunyai bentuk kata marshad yang artinya tempat observasi dan mirshadah artinya teropong. Ibnu al-Mandzur, Lisa>n al-'Arab, (Kairo : Dar al-Ma'arif, 1119), hlm. 1753. Lihat juga di Munawwir A. Fatah dan Adib Bisri, Kamus (Indonesia-Arab) al-Bisri, (Surabaya : Pustaka Progessif, 1999), hlm. 251-252. 
dilakukan oleh banyak orang, adapun hisab hanya terbatas kepada orang yang mengetahuinya. Maka secara tidak langsung bahwa hisab dan rukyah adalah usaha untuk menentukan suatu waktu. Dan pengetahuan tersebut adalah suatu keharusan bagi umat manusia untuk bisa melaksankan transaksi sosial, ibadah, ataupun yang lain.

Rukyatul hilal merupakan salah satu cabang dari penggunaan kata rukyah. Kegiatan ini dilakukan umat Islam dalam penentuan awal bulan kamariyah, yaitu dengan memantau hilal di akhir bulan kamariyah. Dan jika dilihat saat ini, maka pelaksanaan rukyatul hilal sudah menggunakan bantuan alat-alat observasi modern, seperti teleskop dan lain sebagainya.

Keadaan yang ada sekarang, tentunya tidak terlepas dari sejarah panjang penggunaan rukyatul hilal menggunakan alat bantu seperti yang dijumpai sekarang. Sehingga dari sini penulis mencoba menjelaskan rentetan sejarah dari penggunaan rukyah secara umum sampai penggunaannya dalam menentukan hilal awal bulan kamariyah di era modern.

\section{B. Pengertian Hisab dan Rukyah}

\section{Definisi Hisab dan Rukyah}

Secara etimologi hisab berasal dari kata Arab yaitu hasiba-yahsabuhusbanan/hisaban yang artinya perhitungan dan dalam bahasa Inggris disebut arithmatic. Secara istilah ilmu hisab adalah ilmu pengetahuan yang membahas tentang seluk beluk perhitungan atau lebih sederhana adalah ilmu hitung. ${ }^{2}$

Dalam khazanah keilmuan Islam, ada juga yang disebut sebagai ilmu hitung, yaitu ilmu falak dan ilmu faraid. Penyebutan ini karena keduanya sering mengkaji perhitungan-perhitungan, seperti pemecahan bagian-bagian waris, dan lain sebagainya. Namun tidak dengan di Indonesia, ilmu hitung yang dimaksud adalah ilmu falak yang mempunyai fokus kajian perhitungan untuk digunakan umat Islam dalam kegiatan ibadah.

\footnotetext{
${ }^{2}$ Direktorat Jenderal Bimas Islam, Almanak Hisab Rukyat, (Jakarta : KEMENAG, 2010), hlm. 20
} 
Adapun rukyah terambil dari kata ra'a-yara-ru'yatan artinya melihat, yakni observasai atau mengamati benda-benda langit. Dan dikenal pula rukyatul hilal yaitu usaha melihat atau mengamati hilal di tempat terbuka dengan mata bugil atau peralatan pada saat matahari terbenam di akhir bulan tahun kamariyah. Apabila hilal berhasil dilihat, maka malam tersebut dan esoknya adalah tanggal satu untuk bulan berikutnya. Apabila belum terlihat, maka malam tersebut dan esoknya adalah hari ke 30 untuk bulan yang sedang berlangsung. ${ }^{3}$ Hal ini sebagaimana keterangan potongan hadis Nabi Muhammad SAW, yaitu : انما الثهر تسع وعشرون فلا تصوموا حتى yang artinya “ sesungguhnya bulan itu 29 (hari), maka jangan kalian berpuasa sampai kalian melihatnya (hilal) dan jangan kalian berbuka sampai kalian melihatnya juga (hilal). Maka jika terjadi mendung, maka perkirakanlah. ${ }^{4}$

Keterangan hadis di atas juga bahwa " secara makna zahir, dalam penentuan awal puasa dan hari raya hanya dengan rukyatul hilal saja, yaitu terlihatnya hilal di awal Ramadan dan Syawal sesuai dengan keumuman dan keliteralan dari hadis di atas. Dengan kriteria bahwa : jika langit pada tanggal 29 Syakban cerah dan hilal terlihat, maka esok harinya adalah awal puasa. Demikian untuk 29 Ramadan, jika terlihat hilal maka esok harinya adalah pelaksanaan salat idul fitri. Namun, jika keadaan langit mendung maka pelaksanaan puasa dan atau hari raya ditunda sehari dengan menggenapkan bilangan bulan Syakban atau Ramadan menjadi 30 hari. $^{5}$ Adapun dalam perjalanan selanjutnnya, antara hisab dan rukyah dalam aplikasi penentuan ibadah juga kadang tidak sejalan satu sama lain, seperti penentuan awal Ramadan, Syawal, dan Dzulhijjah. ${ }^{6}$

Penulis juga menggarisbawahi bahwa yang dimaksud ilmu hisab dalam makalah ini adalah ilmu hisab sebagai ilmu falak yang digunakan umat Islam dalam

\footnotetext{
${ }^{3}$ Muhyiddin Khazin, Kamus Ilmu Falak, (Yogyakarta : Buana Pustaka, t.t), hlm. 69.

${ }^{4}$ Abi Bakr Ahmad bin Husain bin 'Ali al-Baihaqi, Sunan Kubra, (Beirut : Dar al-Kutub al'Ilmiah, 1994), hlm. 343.

${ }^{5}$ Sakirman, Menelisik Metodologi Hisab-Rukyat di Indonesia, (Hunafa : Jurnal Studia Islamika, Vol, 8, No. 2, Desember 2011, ), hlm. 348.

${ }^{6}$ Encup Supriatna, Hisab Rukyat dan Aplikasinya, (Bandung : Refika Aditama, 2007), hlm. 1.
} 
menjalani kegiatan ibadah. Ia hanya memberikan hasil perhitungan terkait persoalan waktu dan posisi saja, dan tidak dapat mengatakan secara rinci bahwa hilal (bulan) pada posisi tertentu pasti atau mustahil dapat terlihat. ${ }^{7}$

\section{Aplikasi Rukyah dalam Catatan Sejarah \\ Masa Nabi dan Sahabat}

Pada masa Nabi, rukyah digunakan untuk menentukan awal bulan kamariyah baru seperti Ramadan, Syawal, Zulhijjjah dan Muharram. Dalam perjalanannya belum terlihat masalah dalam kegiatan rukyah karena umat Islam hanya ada di Arab saja dan baru ada perbedaan ketika Islam mulai menyebar luas.

Dalam penelusuran penulis melalui hadis-hadis Nabi yang berbicara dengan prosesi rukyah, maka setidaknya ada empat bulan yang dijadikan rutinitas besar umat Islam saat itu. Empat bulan tersebut adalah Ramadan, Syawal, Dzulhijjah, dan Muharram. Dan penjelasan keempat bulan tersebut tidak lain adalah untuk memulai berpuasa Ramadan, memulai idul fitri, mengetahui waktu berkurban, dan mengetahui waktu puasa Asyura. Sebagaimana hadis yang menerangkan awal bulan Ramadan dan Syawal, yaitu :

$$
\begin{aligned}
& \text { أخبرنا أبو بكر محمد بن محمد بن أحمد بن رجاء, ثنا أبو الحسن محمد بن محمد بن } \\
& \text { الحسن الكازي, أنبأ علي بن عبد العزيز, ثنا القعنبي, قال : قرأت على مالك (ح) وأخبرنا } \\
& \text { أبو زكريا بن أبي اسحاق المزكي, ثنا أبو عبد الله محمد بن بعقوب الثيباني, ثنا محمد بن } \\
& \text { نصر, جعفر بن محمد قالا : ثنا يحيى بن يحيى, قال : قرأت على مالك, عن نافع, عن ابن } \\
& \text { عمر, عن النبي صلى الله عليه وسلم أنه ذكر رمضان فقال : لاتصوموا حتى تروا الهلال, } \\
& \text { و لا تفطروا حتى تروه فان أغمي عليكم فاقدروا له. } \\
& \text { وفي رواية القعنبي أن رسول الله صلى الله عليه وسلم ذكر رمضـان وقال : فان } \\
& \text { غم عليكم. } \\
& \text { رواه البخاري في الصحيح عن القعنبي, ورواه مسلم عن يحيى بن بحيى. } 8
\end{aligned}
$$

${ }^{7}$ Ibid. hlm. 2.

${ }^{8}$ Abi Bakr Ahmad bin Husain bin 'Ali al-Baihaqi, Sunan, ... hlm. 343. 


$$
\begin{aligned}
& \text { عن ابي هريرة رضي الله عنه قال قال النبي صلى الله عليه وسلم : صوموا } \\
& \text { لرؤيته و افطروا لرؤيته فان غبي عليكم فاكملوا عدة شعبان ثناثين. (رواه } \\
& \text { البخار ي, و اللفظ لله, ومسلم) }
\end{aligned}
$$

Adapun hadis yang menerangkan tentang awal bulan Dzulhijjah dan awal bulan Muharam, yaitu :

$$
\begin{aligned}
& \text { عن ام سلمة أن النبي صلى الله عليه وسلم قال اذار أيتم هلال ذى الحجة وار اد احدكم أن } \\
& \text { يضحى فليمسك شعرهو أظفاره (رواه مسلم و ابو داود و احمد) }
\end{aligned}
$$

Dari Ummu Salamah (diwartakan) bahwa Nabi SAW bersabda : apabila kamu melihat hilal Zulhijjah sementara seseorang kamu hendak berkurban, maka hendaklah ia membiarkan (tidak mencabut) rambut dan kukunya. (HR. Muslim, Abu Daud, dan Ahmad). ${ }^{9}$

$$
\begin{aligned}
& \text { عن الحكم بن الاعرج قال انتهيت الى ابن عباس رضي الله عنهما وهومتوسد رداءه في } \\
& \text { زمزم فقلت له اخبرني عن صوم عاشور اء فقال اذا رايت هلال المحرم فاعدد واصبح } \\
& \text { يوم التاسع صائما فقلت هكذا كان رسول الله صلى الله عليه وسلم يصومه قال نعم. (رواه } \\
& \text { مسلم) }
\end{aligned}
$$

Dari al-Hakam Ibn al-A'raj (diriwayatkan bahwa) ia berkata : saya pergi menemui Ibn 'Abbas ketika ia baring beralaskan jubahnya di Zamzam. Saya berkata kepadanya : beritahu aku tentang puasa Asyura! Lalu ia menjawab : apabila engkau melihat hilal muharram, maka hitunglah harinya dan puasalah sejak subuh hari kesembilan. Saya bertanya lagi : apakah begini cara Rasulullah SAW melakukan puasa Asyura itu? Ia menjawab : Ya!. (HR. Muslim).

Kita bisa memahami bahwa penggunaan rukyah oleh umat Islam di zaman Nabi SAW erat kaitannya dengan suatu kebutuhan pelaksanaan suatu ibadah, seperti puasa Ramadan, salat idul fitri, pelaksanaan kurban, dan puasa Asyura. Dan pelaksanaan melihat hilal tersebut masih menggunakan kedua mata (mata telanjang).

${ }^{9}$ Muslim, Shahih Muslim, I, 482. Hadis no 41 (1977). Abu Daud, Sunan Abi Daud, (Beirut : Dar al Kutub al'ilmiyah, 2004), hlm. 447. 
Hal ini juga disebut dalam buku al-Mausu> 'ah 'Aba>qirah al-Islamiah fi alFalak wa al-'Ulu>m al-Bahriyah wa 'Ilm al-Naba>t wa 'Ilm Mika>nika oleh Muhammad Husain Farsukh yang menerangkan bahwa "sebelum masa ini (disebutkan pada masa pemerintahan Islam), orang-orang muslim tidak megetahui ilmu falak terkecuali yang berkaitan dengan hajat mereka. Seperti musim hujan dan kemarau, musim haji, waktu salat, dan waktu bulan puasa. Ini sebagai keutamaan dari apa yang disebut dengan ilmu tanjim (ilmu perbintangan) yang berkaitan dengan ahwa $>l$ manusia. ${ }^{10}$

Dalam kajian hisab, kita ketahui bersama bahwa Nabi pernah mengatakan "kita itu umat yang ummi, tidak menulis maupun menghitung”, sehingga keadaan hisab waktu itu belum menjadi kajian di kalangan umat Islam. Oleh karena itu, penentuan awal bulan kamariyah dilakukan dengan rukyatul hilal pada akhir bulan, atau menggenapkan umur bulan menjadi tiga puluh hari. Hal ini sesuai dengan kebiasaan masyarakat Arab pra Islam dan sabda Nabi Muhammad SAW mengenai penentuan awal Ramadan dan Syawal. ${ }^{11}$

Namun tidak bisa dipungkiri juga bahwa hisab sendiri sudah diperkenalkan kepada peradaban manusia dimulai dari bangsa Babilonia yang ketika itu telah memberi kontribusi besar dalam dunia astronomi. Kontribusi tersebut yang akhirnya menjadi cikal bakal kemajuan ilmu pengetahuan dalam mengamati bintang-bintang, yaitu : membuat ramalan hisab untuk mendeteksi terjadinya suatu gerhana, menetapkan keliling bumi menjadi 360 derajat, menetapkan satu hari 24 jam dengan satu jam $=60$ menit dan 60 detik. Hisab pada waktu itu digunakan dalam pemujaan dewa-dewa (astoroth dan ball). ${ }^{12}$

Berlanjut di negara Mesir. Perkembangan hisab dan rukyah yang ada sudah mereka gunakan dalam hal penanggalan yaitu dengan menjadikan kemunculan bintang Sirius sebagai titik pedoman. Hal ini karena bintang Sirius muncul dan

\footnotetext{
${ }^{10}$ Muhammad Husain Farsukh, al-Mausu>'ah 'Abaqirah al-Islamiah fi al-Falak wa al'Ulu>m al-Bahriyah wa 'Ilm al-Naba>t wa 'Ilm Mika>nika, juz 5, (Beirut : Dar al-Fikr al-'Arabi, 1995), hlm. 15.

${ }^{11}$ Ditjen Bimas Islam dan Penyelenggaraan Haji, Selayang Pandang Hisab Rukyat, (Jakarta : KEMENAG, 2004), hlm. 17.

${ }^{12}$ Ahmad Musonnif, Ilmu Falak, (Yogyakarta : Teras, 2011), hlm. 6.
} 
setiap itu pun sungai nil mengalami banjir. Hisab yang ada juga digunakan untuk menetapkan waktu memuja dewa (orisis, isis, dan anom). ${ }^{13}$

Sebelum dimulainya peradaban Islam di bangsa Arab, mereka telah mengenal hisab yang tertanam dalam dunia penanggalan saat itu. Sistem penanggalan yang mendasarkan kepada luni-solar atau penanggalan berdasarkan pergerakan bulan dan matahari. Sistem penanggalan yang ada juga mereka gunakan dalam menentukan masa (waktu) dan karena disana sering dijumpai peperangan. Maka dengan penanggalan tersebut mereka menggunakannya.

Namun demikian, sistem penanggalan saat itu terdapat kerancauan yaitu dalam penetapan tahun kabisatnya. Keadaan itu didasarkan oleh masing-masing suku mempunyai penetapan kabisat sendiri-sendiri, sehingga waktu itu menjadi dalih dan pembenaran untuk menyerang suku-suku lain.

Seiring berkembangnya zaman, Islam masuk dan memberi warna peradaban. Terutama dalam hal sistem hisab penanggalan. Hisab penanggalan mengalami perkembangan yang pesat. Dimana sistem yang dulunya luni-solar maka Islam mengubahnya menjadi lunar calendar ( kalender bulan). Dan bilangan bulan ditetapkan menjadi 12 di mana sebelumnya bangsa Arab menerapkan bulan ketiga belas setiap penghujung tahun kabisat. ${ }^{14}$

Meski demikian, dalam hisab penanggalan tersebut juga masih belum menggunakan angka tahun, sehingga tetap masih menimbulkan kerancauan. Karena jika digunkanan dalam suatu transaksi kerja sama mereka hanya menulis 14 Rajab dan ini menimbulkan kebingungan.

Dalam catatan sejarah ada tokoh Muslim yang bernama Shams al-Di>n Muhammad Ibn Abd al-Rahman al-Sakhawi (w.902) dalam I'la $>n$ bil tawbikh li man dhamma al tawrikh meriwayatkan dengan detail asal usul almanak ini. sebuah laporan yang diotoritaskan kepada Ibnu 'Abbas menyatakan bahwa ketika Nabi SAW tiba di Madinah, memang belum ada sistem almanak. Orang-orang baru

\footnotetext{
${ }^{13}$ Ibid. hlm.7.

${ }^{14}$ Ahmad Musonnif, Ilmu,... hlm. 13.
} 
menggunakannya sekitar 1 atau 2 bulan sesudah kedatangannya. Kebiasaan ini diteruskan sampai Nabi SAW meninggal. ${ }^{15}$

\section{Hisab dan Rukyah di Masa Sahabat}

Berlanjut pada masa sahabat, perkembangan hisab dalam hal penanggalan mendapat saran yang mendukung dalam penyempurnaan, yaitu surat yang dikirim oleh Musa Al-Asy'ari (Gubernur Irak) kepada sahabat Umar Bin Khattab yang saat itu menjabat khalifah. Surat tersebut merekomendasikan diberikannya angka tahun pada penanggalan hijriyah. Dan Umar pun menanggapi dan menyetujui serta terpilih beberapa orang sebagai panitianya (Umar, Utsman bin Affan, Ali bin Abi Thalib, Abdurahhamna bin Auf, Sa'ad bin Abi Waqas, Talhah bin Ubaidillah, dan Zubaer bin Awwam. ${ }^{16}$

Penanggalan Hijriyah yang dicetuskan oleh sahabat Umar bin Khattab menjadi pedoman pertama hisab urfi saat itu. Hisab urfi sendiri adalah sistem perhitungan kalender yang didasarkan pada rata-rata bulan mengelilingi bumi dan ditetapkan secara konvensional. Hisab urfi ini telah digunakan sejak masa khalifah Umar bi Khattab tahun $17 \mathrm{H}$. Penanggalan akan berulang secara berkala setiap tiga puluh (30) tahun. $^{17}$

\section{Hisab di Masa Bani Umayah (40 H-132H / 661M-750M) ${ }^{18}$}

Khalid bin Yazid bin Muawiyah bin Abi Sufyan (w.85 H/704 M) yang menjabat sebagai khalifah bani Umayah waktu itu sebagai tanda dimulainya

\footnotetext{
${ }^{15}$ Slamet Hambali, Almanac Sepanjang Masa, ( Semarang : Program Pascasarjana IAIN Walisongo, 2011), hlm. 13-14.

${ }^{16}$ Target utama dibetuknya panitia ini adalah merumuskan sistem kalender hijriyah yang permulaan tahunnya dimulai berdasarkan tahun kelahiran Nabi $571 \mathrm{M}$, atau berdasarkan turunnya firman Allah yang pertama 610 M. dan usulan sahabat Ali sekaligus yang disepakati oleh forum yaitu berdasarkan tahun hiijrah dari mekah ke madinah ('am al hijrah, $622 \mathrm{M}$ ). baca Amhad Musnonif, Ilmu,... hlm. 15 .

${ }^{17}$ Uum Jumsa, Ilmu Falak, (Bandung : Humaniora, 2006), hlm. 1-2.

${ }^{18}$ Masa pemerintahan dinasi umayah dimulai pada tahun $40 \mathrm{H} / 661 \mathrm{M}$ yang dipelopori oleh Muawiyah bin Abi Sufyan dan selesai pada tahun 132 H/750 M dengan dideklarasikannya dinasti 'Abbassiyah oleh Abu al-'Abbas as-Safah. Yahya Syams, Ilmu Falak, (Beirut : Dar al-Fikr 'Arabi, 1997), hlm. 97.
} 
peradaban ilmu falak (astronomi). Namun dalam perkembangan hisabnya, mereka masih fokus dalam penerjemahan buku-buku astronomi bangsa Yunani. ${ }^{19}$

Perkembangan hisab terbantu oleh hasil penerjemahan karya-karya bangsa Yunani yaitu : The Sphere in Movement (al-kurrah al-mutaharrikah) karya Antolycus, Ascentions of The Signs (matali' al buru>j) karya Aratus, Introduction to Astronomy (al-madhkhal ila ilmi al-falak) karya Hiparchus, dan Almagesty karya Ptolomeus. ${ }^{20}$ Pada pertengahan abad 4 Hijriyah terbukti dengan ditemukannya globe karya Batlamus yang disediakan untuk Khalid bin Yazid di perpus Kairo. $^{21}$

\section{Hisab Dan Rukyah Di Masa Abbasiyah (132H-656H / 749M-1258M) 22}

Dukungan yang isitimwea oleh pemerintah dalam pengembangan ilmu astronomi mengalami dampak yang pesat dalam dunia hisab dan rukyah. Dari sini, mulai dibentuk kajian yang tidak hanya alamiyah melainkan ilmiah, sehingga waktu itu bermunculan tokoh-tokoh ilmu falak yang berhasil menemukan perhitungan waktu salat, arah kiblat, rukyatul hilal, perhitungan musim, dan lainlain. Bisa dikatakan hisab yang ada sudah sangat fenomenal karena berhasil mengukur arah kiblat sebagaimana yang ditemukan oleh al-Biruni. Dan rukyah mulai sering diagendakan dengan penemuan hisabnya. ${ }^{23}$

Ilmu pengetahuan mendapat perhatian besar dan tempat istimewa di pemerintahan tak terkecuali ilmu falak. Tepatnya pada masa khalifah al-Mansur. Dalam perkembangannya, ilmu falak tidak hanya dikembangkan dalam hal ibadah umat Islam saja, melainkan dikembangkan secara luas sebagai bentuk pondasi dasar keilmuan yang bisa ditarik untuk memunculkan ilmu-ilmu yang lain, seperti pelayaran, pertanian, militer, dan lain sebagainya.

\footnotetext{
${ }^{19}$ Masa dinasti Umayah ini diklaim sebagai penterjemahan buku falak pertama dalam sejarah Islam yang diterjemahkan dari bahasa Yunani. Muhammad Husain Farsukh, al-Mausu'ah,... hlm. 15.

${ }^{20}$ Uum Jumsa, Ilmu, ... hlm. 15.

${ }^{21}$ Ahmad Musonnif, Ilmu,... hlm. 15.

${ }^{22}$ Yahya Syams, Ilmu, ... hlm. 100.

${ }^{23}$ Ahmad Musonnif, Ilmu,... hlm. 16
} 
Dukungan pemerintah yang besar terhadap ilmu astronomi, maka ilmu ini terus mengalami perkembangan sampai masa khalifah al-Makmun. Dan hisab mengalami kemajuan pesat dengan munculnya tokoh-tokoh astronomi Islam masa itu seperti al-Battani $^{24}$ (w.317 H), al-Buzjani (w.387 H), Ibnu Yunus (399 H), at-Thusi , alBiruni $^{25}$ (w.442 H), dan lain sebagainya. Pada masa ini hisab dalam penentuan waktu salat, arah kiblat, rukyatul hilal, perhitungan musim, dan lain lain yang telah dituiliskan dalam karya tokoh-tokoh tersebut.

Tradisi terjemah buku-buku astronomi juga mulai marak dilakukan seperti buku Mifta $>h$ an-Nuju>m (Hermes sang filosof). Sindhind / Sindhanta tahun 154 H/771 M, Almagest Ptolomeus oleh Yahya bin Khalid al-Barmaky dan disempurnakan oleh al-Hajjaj bin Muhtar dan Tsabit bin Qurrah (w.288H).

Sejarah mencatat bahwa perkembangan hisab juga mulai diaplikasikan dalam bentuk alat-alat peraga yang dibuat oleh tokoh falak, seperti kontribusi al-Fazari yang membuat astrolabe. ${ }^{26}$ Dikatakan bahwa Ya'qub bin Thariq (w.179H/796M) berhasil menerjemahkan kitab Arkindi dan Tarkibul Afla>k yang didalamnya membahas almanak perbintangan (ephemeris).

Maka bisa disimpulkan bahwa hisab pada masa ini berkembang pesat daripada sebelumnya. Mereka sudah menggunakannya untuk menentukan waktu ibadah umat Islam (salat, puasa, arah kiblat, dan juga musim). Adapun rukyah dalam kaitanya dengan ilmu falak telah dijadikan pondasi dasar untuk menemukanmenemukan ilmu lain. Di samping untuk pembuktian keakuratan hisab itu sendiri dan juga sebagai metode yang sering dilakukan. Hal ini dengan dibangunnya observatorium untuk mengamati benda-benda langit. ${ }^{27}$

${ }^{24}$ Tahun 858-929 M Ibnu Jabr al-Battani memberi kontribusi besar dalam bidang hisab sepeti perhitungan jalan bintang, garis edar, dan gerhana. Dia juga telah mampu membuktikan kemungkinan terjadinya gerhana cincin.

${ }^{25}$ Ilmu hisab mengalami kemajuan lagi setelah Abdurrahman al-Biruni (w.1048) berhasil menemukan perputaran bumi pada sumbunya dan membuat daftar data lintang dan bujur tempat di permukaan bumi yang sekarang menjadi unsur utama dalam perhitungan waktu-waktu ibadah umat Islam ( arah kiblat, waktu salat, gerhana, awal bulan, dan lain sebagainya.)

${ }^{26}$ Ibrahim al-Fazari merupakan orang Arab pertama yang membuat alat observasi untuk mengintai benda-benda langit yaitu yang disebut Astrolabe. Muhammad Husain Farsukh, alMausu'ah,... hlm. 16.

${ }^{27}$ Ahmad Musonif, Ilmu,... hlm. 17. 
Pada abad ke 8 muncul Abu Ja'far Muhammad bin Musa Alkhawarizmi (780847 M) sebagai ketua observatorium al-Makmun. Sumbangannya dalam hisab sangat besar di antaranya adanya angka 0, tabel trogonometri (daftar logariitma), zodiak ekliptika miring 23.5 terhadap ekuator. Dan karya ini tidak terlepas dari jasa al-Fazari yang berhasil menerjemahkan buku Sindhind / Sindhanta. Dan kontribusi terbesarnya dalam ilmu hisab adalah 2 bukunya al-Mukhtasha>r fi Hisab al-Jabr wa al-Muqa>balah dan Su>ratul Ardl.

Abu Ma'syar (w.880 M) berhasil menemukan konsep hisab dalam menentukan pasang surut air laut sebagai dampak dari gerak bulan terhadap bumi. Dalam dunia rukyah / observasi lebih maju lagi dengan adanya Ibrahim bin az-Zarqali (10291089) yang di barat dikenal dengan Arzachel. Ia dikenal dengan teropong bintangnya dan dari sini ia berjasa dalam daftar tabel astronomi bintang-bintang. Tentunya peran rukyah saat itu sangat luas, tidak hanya dalam hal ibadah umat Islam melainkan sebagai pondasi dasar atas keilmuan-keilmuan lain.

Tahun 1201-1274 M perkembangan rukyah (observasi) juga semakin berkembang dengan dibangunya observatorium di Maragha atas perintah Hulagu. Sumbangan dari hasil yang diperoleh rukyah / pengamatan tersebut adalah berupa data astronomi umum yang diberi judul $J a d w a>l u l$ Kaniya $>n$.

Ulugh Beik w.1420 M asal Iskandaria juga ikut memberi kontribusi besar dalam dunia hisab / rukyah. Dengan usahanya di suatu observatorium ia berhasil menyumbangkan tabel data astronomi yang hingga kini menjadi sejarah hisab Indonesia.

\section{Hisab dan Rukyah Abad Pertengahan dan Modern}

Rukyah / observasi mengalami kemajuan yang baik ketika Galileo Galilei menemukan metode observasi sebagai kajian ilmiah. Ia sendiri hidup pada abad ke $16 \mathrm{M}$ dan memberi jalan bagi pengetahua modern. ${ }^{28}$ Namun demikian, tidak bisa dipungkiri bahwa sejatinya Nabi SAW sendiri sudah menekankan rukyah ketika hendak melakukan ibadah puasa, sebagaimana hadis di atas.

\footnotetext{
${ }^{28}$ Ibid. hlm. 26.
} 
Dari sini peran hisab dan rukyah mengalami perkembangan yang luar biasa, tidak hanya untuk ibadah umat Islam namun dalam kegiatan-kegiatan manusia lainnya seperti berdagang, berlayar, bertani, dan lain-lain. ${ }^{29}$

\section{Ulugh Beik}

Dari adanya tabel data astronomis Ulugh Beik (1344-1449 M) maka secara tidak langsung adalah bentuk dasar yang mewarnai ragam hisab di Indonesia. Temuan Ulugh Beik itu sendiri pada tahun 1650 M diterjemahkan ke beberapa bahasa asing, seperti Inggris dan Perancis.

Ada juga peletak dasar dari ragam hisab modern di Indonesia, yaitu dengan hadirnya Simon New Comb (1835-1909 M) yang berhasil membuat jadwal astronomi baru ketika kebetulan berkantor di Nautical Almanac Amerika (18571861) yang telah dikenal dengan almanac nautica dan dipakai di Indonesia. ${ }^{30}$

\section{HISAB DAN RUKYAH DI INDONESIA}

Kajian hisab dan rukyah di Indonesia dalam pandangan penulis juga tidak terlepas dari bentuk konfirmasi fiqh ibadah seperti salat, puasa, awal bulan, dan penanggalan.

Ragam hisab yang berkembang tidak lain sangat erat dengan kontribusi tabel Ulugh Beik yang kemudian menjadi tipologi ilmu falak di Indonesia. Dan bisa dijumpai dalam literatur klasik seperti Sullamun Nayyirain. Adapun ragam lainnya adalah hisab modern (kontemporer) yang mengadopsi dari almanac nautika. Sehingga secara umum di Indonesia sendiri telah ada ragam hisab klasik dan modern. Begitu juga kaitannya rukyah yang fokus ke dalam masalah awal bulan hijriyah. $^{31}$

Sejarah mencatat bahwa sebelum Islam datang, di Indonesia sudah mengenal hisab (perhitungan) penanggalan, yaitu kalender Jawa Hindu / Tahun Saka yang dimulai hari Sabtu, 14 Maret 78 M. Yakni tahun penobatan Prabu Syaliwahono (Aji Soko). Kalender ini dipakai oleh umat Budha di Bali dan setelah Islam datang

${ }^{29}$ Muhyiddin Khazin, Ilmu Falak Dalam Teori dan Prakktik,( Yogyakarta : Buana Pstaka, t.t), hlm. 23-25.

${ }^{30}$ Ibid. hlm.11. 2009), hlm. 11.

${ }^{31}$ Syaikh Rasyid Ridha, Hisab Awal Bulan Kamariyah, (Yogyakaarta : Suara Muhamadiyah, 
kalender tersebut mengalami transformasi ke bentuk kalender hijriyah tepatnya pada 1043 H/1633 M (1555 tahun soko) oleh Sultan Agung. Konsep kalender sendiri berdsarkan peredaran bulan dan tahunya tetap memakai 1555 (tahun saka).

Corak hisab yang berkembang di Indonesia juga tidak lepas dari pemikiran falak Syekh Husein Zaid al-Misra yang punya buku al-Mathla > 'ul Said fi Hisabiil Kawa>kib 'ala Rasydil Jadi>d. Kitab falak di Indonesia kebanyakan dijumpai di pesantren-pesantren yang diajarkan oleh sang kyai kepada muridnya guna mendalami ilmu falak. Terutama pesantrren di Jawa dan Sumatera.

Ada karakter yang dimiliki oleh ahli falak di Indoneisa, yakni epoch dalam kitabnya biasanya menisbahkan kepada tempat tinggalnya masing-masing, seperti Nawawi Muhammad Yunus al-Kadiri dengan epoch Kediri dan lain sebagainya. ${ }^{32}$

Dari banyaknya ahli falak di indoneisa tersebut, maka seiring berjalannya waktu, pemerintah mengadakan sebuah klasifikasi ragam hisab tersebut melalui berbagai kitab. Pemilihan tersebut diasumsikan untuk mengklasifikasi tingkat keakurantaanya. Dan hisab tersebut di dapat di antaranya :

1. Hisab hakiki taqribi

2. Hisab hakiki tahkiki

3. Hisab haikiki kontemporer.

Namun upaya pemerintah tersebut ternyata ada juga yang masih menganggap bahwa kalangannya sudah akurat hisabnya. ${ }^{33}$

\section{Kesimpulan}

Berdasarkan uraian singkat di atas, maka penulis menarik kesimpulan bahwa hisab merupakan kajian perhitungan yang telah ada sebelum Islam ada. Dan kajian tersebut manusia gunakan untuk menandai suatu masa. Pada masa Nabi SAW, keadaan hisab memang belum berkembang terlebih penanggalan hijriyah yang akhirnya tercetus waktu itu juga hanya sekedar bulan dan tanggal. Adapun rukyah yang menjadi kajian saat itu ketika hendak melaksanakan ibadah puasa, salat masih

\footnotetext{
${ }^{32}$ Ibid. hlm.13.

33 Ibid. hlm. 15.
} 
dengan engamati benda-benda langit (rukyatul hilal). Tercatat rukyah saat iitu yang terekam oleh hadits adalah awal Ramadan, Syawal, Zulhijjah, dan Muharram.

Masa sahabat kajian hisab mengalami perembangan yakni di dalam konsep penanggalan yang sudah memakai angka tahun. Adapun dalam kajian rukyahnya masih seperti apa yang dilakukan oleh Nabi SAW

Dinasti Umayah menjadi langkah awal dalam perkembangan ilmu falak saat itu yakni dengan mulai dialihbahasakan karya-karya buku Yunani ke dalam bahasa Arab. Dilanjut dengan masa dinasi Abbassiyah yang menjadi gerakan paling banyak dalam pengembangan-pengembangan ilmu pengetahuan, terutama ilmu falak. Hal ini dengan dibangunnya observatorium, penerjemahan buku-buku Yunani, India, dan lain sebagainya.

Era modern dimulai dengan munculnya ilmu teknologi seperti teleskop yang dibuat oleh Galileo Galilei sehingga era selanjutnya rukyah mengalami kemajuan pesat dengan menghasilkan data-data astronomis yang akhirnya diadopsi oleh tokoh-tokoh Islam selanjutnya. Dan hingga sampailah ke Indonesia.

Demikianlah presentasi makalah kesempatan ini, penulis sangat memohon maaf atas kekurangan yang ada. Dan semoga makalah kecil ini bisa menjadi pemancing untuk mengkaji lebih mendalam. Sekian, terima kasih. 


\section{DAFTAR PUSTAKA}

A. Fatah, Munawwir, dan Adib Bisri, Kamus (Indonesia-Arab) al-Bisri, Surabaya : Pustaka Progessif, 1999).

Ahmad, Abi Bakr bin Husain bin 'Ali al-Baihaqi, al-Sunan al-Kubra, (Beirut : Dar al-Kutub al-'Ilmiah, 1994).

al-Mandzur, Ibnu, Lisan al- 'Arab, (Kairo : Dar al-Ma'arif, 1119).

Direktorat Jenderal Bimas Islam, Almanak Hisab Rukyat, (Jakarta : KEMENAG, 2010).

Ditjen Bimas Islam dan Penyelenggaraan Haji, Selayang Pandang Hisab Rukyat, (Jakarta : KEMENAG, 2004).

Hambali, Slamet, Almanak Sepanjang Masa, ( Semarang : Program Pascasarjana IAIN Walisongo, 2011).

Husain Farsukh, Muhammad, al-Mausu'ah 'Abaqirah al-Islamiah fi al-Falak wa al'Ulum al-Bahriyah wa 'Ilm al-Nabat wa 'Ilm Mikanika, juz 5, (Beirut : Dar al-Fikr al-'Arabi, 1995).

Jumsa, Uum, Ilmu Falak, (Bandung : Humaniora, 2006).

Khazin, Muhyiddin, Ilmu Falak Dalam Teori dan Prakktik,( Yogyakarta : Buana Pustaka, t.t).

Khazin, Muhyiddin, Kamus Ilmu Falak, (Yogyakarta : Buana Pustaka, t.t).

Muslim, Shahih Muslim, I, 482. Hadis no 41 (1977). Abu Daud, Sunan Abi Daud, (Beirut : Dar al Kutub al'ilmiyah, 2004).

Musonnif, Ahmad, Ilmu Falak, (Yogyakarta : Teras, 2011).

Ridha, Syaikh Rasyid, Hisab Awal Bulan Kamariyah, (Yogyakaarta : Suara Muhamadiyah, 2009).

Sakirman, Menelisik Metodologi Hisab-Rukyat di Indonesia, (Hunafa : Jurnal Studia Islamika, Vol, 8, No. 2, Desember 2011, ).

Supriatna, Encup, Hisab Rukyat dan Aplikasinya, (Bandung : Refika Aditama, 2007).

Syams, Yahya, Ilmu Falak, (Beirut : Dar al-Fikr 'Arabi, 1997). 